\title{
Whole body and tissue protein synthesis in cattle
}

\author{
BY G. E. LOBLEY, VIVIEN MILNE, JOAN M. LOVIE, \\ P. J. REEDS AND K. PENNIE \\ Rowett Research Institute, Bucksburn, Aberdeen $A B 29 S B$
}

$$
\text { (Received } 30 \text { July } 1979 \text { - Accepted } 25 \text { October 1979) }
$$

1. The daily rates of synthesis of protein by the whole body and by the individual tissues were determined
in two Hereford $\times$ Friesian heifers $(236 \mathrm{~kg}$ and $263 \mathrm{~kg}$ live weight), and a dry Friesian cow (628 kg live
weight).

2. The rate of whole-body protein synthesis ( $g$ protein/d) was estimated from the total flux through the blood of $\left[{ }^{3} \mathrm{H}\right]$ leucine and $\left[{ }^{3} \mathrm{H}\right]$ tyrosine following infusion at a constant rate for $8 \mathrm{~h}$.

3. The fractional rates of protein synthesis $\left(k_{s}\right)$ in the tissues ( $\mathrm{g}$ synthesized/d per $\mathrm{g}$ tissue protein) were obtained after slaughter of the animals at the end of the infusion period. The fractional rate of protein synthesis was calculated assuming that the specific radioactivity of free tyrosine in either the blood (to give $k_{s, b}$ ) or the tissue homogenate (to give $k_{s, h}$ ) defined closely the specific radioactivity of the amino acid precursor for protein synthesis. Total protein synthesis $\left(A_{s, b}\right.$ or $\left.A_{s, h} ; \mathrm{g} / \mathrm{d}\right)$ in an individual tissue was calculated as the product of $k_{s, b}$ (or $k_{s, h}$ ) $\times$ protein content.

4. Based on the total leucine flux, i.e. without correction for oxidation, $1.6 \mathrm{~kg}$ protein were synthesized daily in the heifers; for the cow this value was $2 \cdot 0 \mathrm{~kg} / \mathrm{d}$.

5. The sum of the daily total synthesis in the major tissues (muscle + bone + brain, gastrointestinal tract (GIT), liver, hide) gave values of $1 \cdot 4-1 \cdot 9 \mathrm{~kg} / \mathrm{d}$ based on $A_{s, b}$, and $2 \cdot 2-3 \cdot 0 \mathrm{~kg} / \mathrm{d}$ based on $A_{s, h}$.

6. The percentage contributions of the individual tissues to the total protein synthesis were similar in all three animals, for example based on $A_{s, h}$ muscle was 12-16; carcass (muscle + bone+brain) 32-33; GIT 38-46; liver 7-8; skin $14-21 \%$.

7. The contribution of muscle to total synthesis estimated from the leucine flux was $19-22 \%$; this value is in agreement with those calculated on the same basis for other species.

8. The energy cost of protein synthesis was estimated to account for a maximum of $30 \%$ of heat production.

The deposition of protein in the body depends upon the difference in the amounts of protein synthesized and degraded per unit time. It is an energy-dependent process influenced by nutritional, environmental, hormonal and genetic treatments. In recent years considerable effort has been directed towards the measurement of this process, both in the whole animal and in individual tissues, with a view to understanding those factors which control and influence growth.

Values for the rate of whole-body synthesis of protein, estimated from the irreversible loss from the blood of radioactive amino acid (the flux) have been reported for man (James et al. 1976), pigs (Garlick et al. 1976; Reeds et al. 1978; Simon, Münchmeyer et al. 1978; Edmunds et al. 1978) and sheep (Buttery et al. 1975; Buttery et al. 1977). In some of the latter reports values for the fractional rates of protein synthesis in individual tissues have been included and estimates of the contribution of these tissues to the total body protein synthesis have been made.

The tissue most studied has been skeletal muscle but even within a species there has been considerable controversy as to its contribution, for example for man (cf. Halliday \& McKeran, 1975; Young \& Munro, 1978), for pigs (cf. Garlick et al. 1976; Edmunds et al. 1978), and for sheep (cf. Buttery et al. 1975; Arnal et al. 1978). One serious problem in interpretation of the results available from these studies is the variety of methods which have been used to estimate tissue and, in particular, whole-body protein synthesis. It is probable that some of the inter-study variations reflect technical, rather than real, differences. It is important to resolve whether the contribution of the individual tissues differs between 
species, or even within a species dependent on the developmental or nutritional status of the animal, before efforts can be made to influence these contributions for improved animal production.

No information has hitherto been available for cattle. This paper reports measurements of protein synthesis in the tissues and the whole bodies of two growing heifers and a dry cow. Total synthesis in the animals was measured in three ways, i.e. from the sum of the rates determined for individual tissues, the flux of blood free leucine, and the flux of blood free tyrosine. A preliminary report of this study has already appeared (Lobley, Reeds et al. 1978).

\section{METHODS}

\section{Animals}

Two Hereford $\times$ Friesian heifers (nos. 439 and 440), 10.5 and I months old respectively, and an 8-year-old Friesian dry cow (no. 98I) were studied. Each animal was fitted with a bladder catheter (Warne Surgical Products Ltd, Andover, Hants), $10 \mathrm{~d}$ before, and with two jugular catheters (NT3; Portex Ltd, Hythe, Kent) $24 \mathrm{~h}$ before the infusion.

\section{Feeding}

The animals were fed a mixed concentrate diet $(\mathrm{g} / \mathrm{kg} ; 830$ barley, 150 soya-bean meal, 20 steamed bone flour) and hay. All three animals were weighed at least once every $14 \mathrm{~d}$ during the 6 months before the infusions. Cow no. 981 was fed twice daily $2 \mathrm{~kg}$ concentrate and I $\mathrm{kg}$ hay; this was calculated to supply $60 \mathrm{MJ}$ metabolizable energy/d and $650 \mathrm{~g}$ crude protein (nitrogen $\times 6.25$ ) $/ \mathrm{d}$. The cow ate all the ration and her weight at the date of the infusion was the same as that 4 months previously.

The two heifers were allowed access ad lib. to the diet between $100 \mathrm{~kg}$ to $220 \mathrm{~kg}$ live weight and during this period the average weight gains $(\mathrm{kg} / \mathrm{d}$ ) were 0.97 (heifer no. 439) and I 05 (heifer no. 440). About 10 weeks before the infusions the voluntary food intake of both heifers decreased and although the animals were thereafter offered the same amount of ration as the cow it was not all consumed. The amount eaten was not recorded but average live weight gains $(\mathrm{kg} / \mathrm{d})$ for this period were reduced to 0.68 and 0.55 respectively. Heifer no. 440 was of a nervous disposition and showed slight signs of diarrhoea on the day of the infusion.

\section{Infusions}

L- $\left[\right.$ side chain $2,3{ }^{3} \mathrm{H}$ ]tyrosine $(13.3 \mathrm{Ci} / \mathrm{mmol})$ and $\mathrm{L}-\left[4,5{ }^{3} \mathrm{H}\right]$ leucine $(\mathrm{I} \cdot \mathrm{O} \mathrm{Ci} / \mathrm{mmol})$ were obtained from the Radiochemical Centre, Amersham, Bucks, L- $\left[\right.$ ring 2,6- $\left.{ }^{3} \mathrm{H}\right]$ tyrosine was obtained from NEN Chemicals GmbH, Frankfurt, W. Germany. The infusion mixtures contained $0.4 \mathrm{mCi}\left[{ }^{3} \mathrm{H}\right]$ leucine and $2.0 \mathrm{mCi}\left[{ }^{3} \mathrm{H}\right]$ tyrosine/ $/ 100 \mathrm{~kg}$ animal live weight and were diluted to $20 \mathrm{ml}$ with sterile saline (final concentration $9 \mathrm{~g}$ sodium chloride/l); no carrier amino acid was added. Heifer no. 439 and the cow received L-[side chain $2,3-{ }^{3} \mathrm{H}$ ]tyrosine and heifer no. 440 received L- $\left[2,6\right.$ ring $\left.{ }^{3} \mathrm{H}\right]$ tyrosine. Infusions were performed using a Slow Infusion Apparatus (Scientific and Research Instruments Ltd, Edenbridge, Kent) at a rate of $2.05 \mathrm{ml} / \mathrm{h}$ for a period of $8 \mathrm{~h}$. The animals were allowed access to food and water throughout this period. Blood samples $(20 \mathrm{ml})$ were removed at $30 \mathrm{~min}$ intervals during the first $3 \mathrm{~h}$ of the infusion and once hourly thereafter. The blood was collected in tubes containing $2.5 \mu \mathrm{mol}$ norleucine and 25 i.u. heparin and immediately stored at $-20^{\circ}$.

\section{Tissue preparations}

The infusions were continued up to the moment of slaughter when the animals were killed by intravenous injection of sodium pentabarbitone. This latter procedure can be expected 
to reduce cell sloughing in the gastrointestinal tract (GIT) (Fell, 196I). Tissues were excised immediately, chopped or minced and frozen in liquid nitrogen. Samples were removed from the hide ( $.5 \mathrm{~m}$ square section from the back and flank), the m. longissimus dorsi $(\mathrm{I} .5-2.0 \mathrm{~kg})$, liver $(\mathrm{I} \cdot \mathrm{ogg})$ and the washed-out duodenum ( $1.0 \mathrm{~m}$ length). The remainder of the body was then dissected into the main tissues or organs, i.e. hide, liver, GIT, and the carcass (defined as the eviscerated animal without the hide and with the hooves removed distal to the radius and ulna and the tibia and fibula). These were each weighed and minced before representative portions were dried and the $\mathrm{N}$ content determined by a Kjeldahl method (Davidson $e t$ al. 1970).

\section{Analysis}

Urine. Urine samples from the $5 \mathrm{~d}$ before the infusion were assayed for ammonia (Fawcett \& Scott, 1960) and urea (Marsh et al. 1965).

Specific radioactivity of free amino acids. Blood samples were thawed and the protein precipitated by the addition of sulphosalicylic acid to a final concentration of $70 \mathrm{~g} / \mathrm{l}$. After centrifugation the supernatant fraction was applied to a $100 \times 23 \mathrm{~mm}$ Amberlite CG-I 20 (100-200 mesh) column (BDH Ltd, Poole, Dorset) equilibrated in the hydrogen ion form. The column was washed with water until the extinction of the eluate at $280 \mathrm{~nm}$ was less than $\mathrm{O} \cdot \mathrm{I}$, and the amino acids were then eluted with $200 \mathrm{ml}$ of $2 \mathrm{M}$-ammonium hydroxide. The eluate was concentrated under reduced pressure and dissolved in $5 \mathrm{ml} \mathrm{of}$ O. I M-hydrochloric acid. Portions $(2 \mathrm{ml})$ were chromatographed on an amino acid analyser (The Locarte Co., London W I4) in the preparative mode (Nicholas et al. I977) with 0.2 M-sodium citrate, $\mathrm{pH} \mathrm{3.85}$. The fractions which contained leucine, norleucine and tyrosine were then assayed for amino acid content on the amino acid analyser and for radioactivity in a liquid scintillation spectrometer (Packard Tri-Carb Model 3315; Packard Instrument Co., Illinois, USA), using NE26o scintillation cocktail (Nuclear Enterprises (GB) Ltd, Edinburgh).

Tissue samples ( $40 \mathrm{~g}$ ) were homogenized (ILA Homogenizer Model Xıo; Internationale Laboratoriums-Apparate $\mathrm{GmbH}$, Dottingen, W. Germany) in $60 \mathrm{ml}$ ice-cold $0.08 \mathrm{mM}$ norleucine solution before sulphosalicylic acid was added to a final concentration of $70 \mathrm{~g} / \mathrm{l}$. After centrifugation the supernatant fraction was treated as for the blood samples. The protein precipitate was retained.

Specific radioactivity of protein-bound tyrosine. The protein precipitates were dried, hydrolysed and chromatographed on the amino acid analyser as described by Nicholas et al. (1977). The hide-protein samples were not washed with $0.5 \mathrm{M}$-sodium hydroxide as this would solubilize much of the collagen present. A series of six to ten chromatographs was performed for each tissue sample and those fractions which contained tyrosine were pooled. The solution was then adjusted to $\mathrm{pH} \mathrm{I}-2$ and applied to the Amberlite CG-I 20 (100-200 mesh) column as described previously. The resin was washed with ten bed vol. water and the tyrosine then eluted with $200 \mathrm{ml} 2 \mathrm{M}-\mathrm{NH}_{4} \mathrm{OH}$. The eluate was concentrated under reduced pressure and the residue dissolved in $10 \mathrm{ml} 0.1 \mathrm{M}-\mathrm{HCl}$. A portion was assayed for tyrosine content on the amino acid analyser and a further $5 \mathrm{ml}$ were assayed for radioactivity in $10 \mathrm{ml}$ liquid scintillator (Picofluor TM 30; Packard Instruments Ltd, Caversham, Berks) using a liquid-scintillation spectrometer (Beckman LS-345, Beckman Ltd, Glenrothes, Fife). No sample had less than 700 counts/min per $5 \mathrm{ml}$.

Amino acid content of tissues. Triplicate portions $(250 \mathrm{mg})$ of the dried tissue samples, used for the determination of $\mathrm{N}$ content, were hydrolysed under reflux for $24 \mathrm{~h}$ at $110^{\circ}$ in $200 \mathrm{ml} 6 \mathrm{M}-\mathrm{HCl}$, containing $25 \mu \mathrm{mol}$ norleucine. The acid was removed under reduced pressure, and the residue dissolved in $0.1 \mathrm{M}-\mathrm{HCl}$. The contents of leucine and tyrosine were determined on the amino acid analyser; losses on hydrolysis and transfer were corrected by reference to the internal standard of norleucine. 
The 4-hydroxyproline content of these samples was determined by the colorimetric method of Firschein \& Shill (1966), and this was converted to collagen- $N$ by multiplying by $1 \cdot 42$. Subtraction of collagen-N from total carcass $N$ gave the amount of muscle $N$ present.

Calculation of results. The basic equation derived by Garlick et al. (1973) was used for all treatments as described by Nicholas et al. (1977).

$$
\frac{S_{B}}{S_{x}}=\frac{\phi}{\phi-k_{s}} \times \frac{\mathrm{I}-e^{\cdots+k_{s} t}}{\mathrm{I}-e^{-\phi t}}-\frac{k_{s}}{\phi-k_{s}},
$$

where $S_{x}$ and $S_{H}$ are the time-dependent specific radioactivities of the precursor and proteinbound amino acid respectively, $\phi$ is a rate-constant describing the change in $S_{x}, t$ is time (d) and $k$, is the fractional rate of protein synthesis ( $g$ protein synthesized/d per $g$ tissue protein). The value of $\phi$ was determined experimentally from the serial blood samples and was assumed the same for the tissues (see Nicholas of al. 1977; Simon, Bergner et al. 1978).

The irreversible loss of radioactivity from the blood free pool, the 'flux', was determined from the specific radioactivity of the blood free amino acid at 'plateau' as described by James et al. (1976). An average value was calculated from the samples taken during the last $5 \mathrm{~h}$ of the infusion.

\section{RESULTS}

\section{Body composition}

The total protein $(\mathrm{N} \times 6.25)$ and tyrosine and leucine content of each tissue are included in the results for gross composition given in Table $\mathrm{I}$. In the instance of the cow the hide samples, taken for the determination of $N$, proved unsatisfactory and a value for the total protein of this tissue was taken to be $1 \mathrm{I} \cdot 3 \mathrm{~kg}$ (M. Kay, private communication, a value for Friesian cattle of the same weight but not the same age or sex).

\section{Attainment of 'plateau' condition}

In all three animals the rate of rise in the specific radioactivity of the blood free tyrosine and leucine was rapid; the lowest rate-constant observed for tyrosine was $35 / \mathrm{d}$ for heifer no. 439 (Fig. I). The variation in specific radioactivity of blood free tyrosine at plateau $(3-8 \mathrm{~h})$ was greatest in cow $98 \mathrm{I}(\mathrm{SD} \pm 5.6 \%)$ and least in heifer no. 439 (SD $\pm 2.2 \%$ ). Similar between-animal variations were also observed for leucine. The concentration of the free leucine and free tyrosine in the blood remained steady during the infusion. For a minimum of nine samples taken throughout the infusion for each animal the greatest variation observed for tyrosine was a standard deviation of $\pm 6.0 \%$ and for leucine $\pm 6.5 \%$.

\section{Fractional rate of protein synthesis}

Estimation of the fractional rate of protein synthesis predicates a knowledge of the specific radioactivity of the free amino acid precursor (the amino-acyl t-RNA). Since this was not determined directly the fractional rates have been calculated in two ways. In the first $\left(k_{s, b}\right)$ the precursor specific radioactivity was taken to be that of the blood free tyrosine, and in the second $\left(k_{s, h}\right)$ that of the tissue homogenate free tyrosine. These provide different estimates of the fractional rate of synthesis (see Table 2 ).

The specific radioactivity of the protein-bound tyrosine in $\mathrm{m}$. longissimus dorsi was taken as representative of the total skeletal muscle (protein samples from the $\mathrm{m}$. vastus lateralis were found to have specific radioactivities $5-7 \%$ lower while those from $\mathrm{m}$. masseter were $9-13 \%$ higher than samples from $\mathrm{m}$. longissimus dorsi). As the animals were not exsanguinated before removal of the tissues contamination of these with blood proteins of 
Table 1. Age and weight of cattle and composition of the main tissues

\begin{tabular}{|c|c|c|c|}
\hline $\begin{array}{l}\text { Animal no. } \\
\text { Age (years) } \\
\text { Live wt (kg) } \\
\text { Ingesta-free body-wt }(\mathrm{kg})\end{array}$ & $\begin{array}{l}439 \\
0.9 \\
236 \\
204\end{array}$ & $\begin{array}{l}440 \\
0.9 \\
263 \\
238\end{array}$ & $\begin{array}{l}981 \\
8 \cdot 0 \\
628 \\
551\end{array}$ \\
\hline $\begin{array}{l}\text { Carcass: } \\
\text { Wt }(\mathrm{kg}) \\
\text { Protein }(\mathrm{kg}) \\
\text { Leucine in protein }(\mathrm{mg} / \mathrm{g}) \\
\text { Tyrosine in protein }(\mathrm{mg} / \mathrm{g})\end{array}$ & $\begin{array}{l}132 \cdot 7 \\
23 \cdot 5 \\
60 \\
26\end{array}$ & $\begin{array}{l}151 \cdot 3 \\
25 \cdot 5 \\
62 \\
24\end{array}$ & $\begin{array}{l}338 \cdot 3 \\
62 \cdot 1 \\
63 \\
25\end{array}$ \\
\hline Muscle protein* $(\mathrm{kg})$ & $17+3$ & $17 \cdot 3$ & $48 \cdot 0$ \\
\hline $\begin{array}{l}\text { Liver: } \\
\text { Wt }(\mathrm{kg}) \\
\text { Protein }(\mathrm{kg}) \\
\text { Leucine in protein }(\mathrm{mg} / \mathrm{g}) \\
\text { Tyrosine in protein }(\mathrm{mg} / \mathrm{g})\end{array}$ & $\begin{array}{l}3 \cdot 1 \\
0 \cdot 6 \\
80 \\
32\end{array}$ & $\begin{array}{l}3 \cdot 1 \\
0.6 \\
82 \\
35\end{array}$ & $\begin{array}{l}7 \cdot 3 \\
1 \cdot 4 \\
8 I \\
33\end{array}$ \\
\hline $\begin{array}{l}\text { GIT: } \\
\text { Wt }(\mathrm{kg}) \\
\text { Protein }(\mathrm{kg}) \\
\text { Leucine in protein }(\mathrm{mg} / \mathrm{g}) \\
\text { Tyrosine in protein }(\mathrm{mg} / \mathrm{g})\end{array}$ & $\begin{array}{l}24 \cdot 3 \\
1 \cdot 9 \\
70 \\
24\end{array}$ & $\begin{array}{l}20 \cdot 7 \\
1 \cdot 9 \\
72 \\
24\end{array}$ & $\begin{array}{l}78 \cdot 1 \\
4 \cdot 9 \\
70 \\
25\end{array}$ \\
\hline $\begin{array}{l}\text { Hide: } \\
\text { Wt }(\mathrm{kg}) \\
\text { Protein }(\mathrm{kg}) \\
\text { Leucine in protein }(\mathrm{mg} / \mathrm{g}) \\
\text { Tyrosine in protein }(\mathrm{mg} / \mathrm{g})\end{array}$ & $\begin{array}{l}21 \cdot 7 \\
7 \cdot 8 \\
57 \\
20\end{array}$ & $\begin{array}{l}22 \cdot 7 \\
7 \cdot 4 \\
47 \\
20\end{array}$ & $\begin{array}{l}40 \cdot 0 \\
11 \cdot 3 \dagger \\
53 \\
20\end{array}$ \\
\hline $\begin{array}{l}\text { Whole-body protein } \ddagger(\mathrm{kg}) \\
\text { Leucine in protein } \$(\mathrm{mg} / \mathrm{g}) \\
\text { Tyrosine in protein } \$(\mathrm{mg} / \mathrm{g})\end{array}$ & $\begin{array}{l}34 \cdot 0 \\
60 \\
24\end{array}$ & $\begin{array}{l}35 \cdot 4 \\
60 \\
23\end{array}$ & $\begin{array}{l}79 \cdot 7 \\
62 \\
24\end{array}$ \\
\hline \multicolumn{4}{|c|}{$\begin{array}{l}\text { GIT, gastrointestinal tract. } \\
\text { * Obtained from (total nitrogen-collagen- } N \text { ) } \times 6 \cdot 25 \text {. } \\
\dagger \text { Value obtained from } \mathrm{M} \text {. Kay (unpublished result). } \\
\ddagger \text { Total protein in four tissues. } \\
\S \text { From total amino acid in protein } \div \text { total protein. }\end{array}$} \\
\hline
\end{tabular}

high specific radioactivity might have led to an over-estimate of the rate of synthesis in the samples. This was investigated in $\mathrm{m}$. longissimus dorsi, from which myofibrils were prepared as described by Perry \& Zydowo (1959). The values for the specific radioactivity of the myofibrillar protein:specific radioactivity of total muscle were $0.96,0.80$ and 0.76 for the animals nos. 439,440 and $98 \mathrm{I}$ respectively. In general the specific radioactivities of myofibrillar and sarcoplasmic proteins are similar in studies on other species (see Lobley \& Lovie, 1979) and, if the situation is similar in cattle, then contamination of total muscle samples with blood proteins introduces an error of 5-20\%. In order to calculate the fractional rate of synthesis of the carcass protein it was assumed that the specific radioactivity of the free tyrosine of the homogenate was the same as that for muscle. The specific radioactivity of protein-bound tyrosine in the complete minced GIT was found to be similar to that from the rapidly-excised section of the duodenum (GIT:duodenum, 1.01, 0.87, 0.79 for animals nos. 439,440 and $98 \mathrm{I}$ respectively). The values of protein-bound specific radioactivity obtained for the GIT may well represent an underestimate as material synthesized and secreted or sloughed into the lumen during the infusion will not be included in the values. Similarly liver will be underestimated by the magnitude of those proteins synthesized in that tissue but which are exported during the experimental period. 


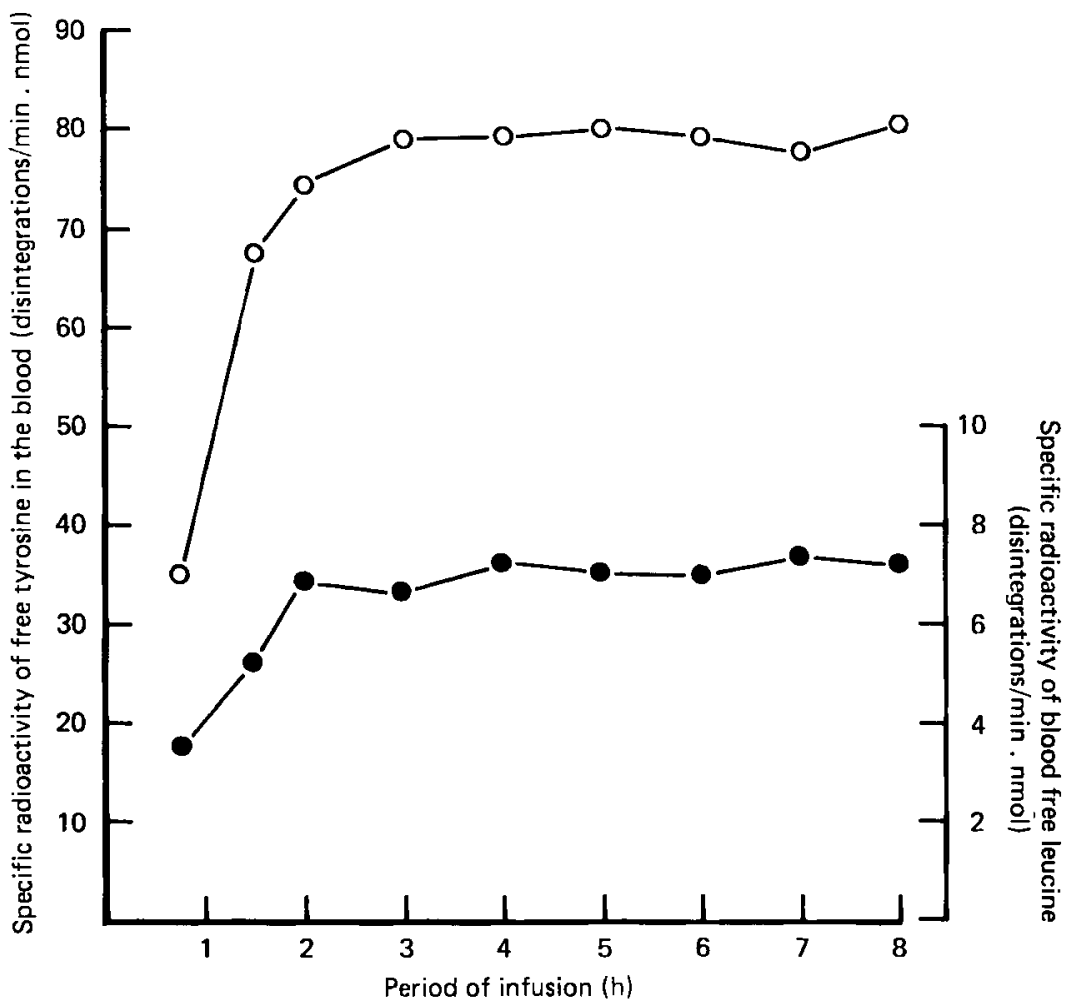

Fig. I. Specific radioactivity (disintegrations/min per nmol) of free tyrosine and free leucine in blood samples from heifer no. $439(236 \mathrm{~kg}$ live weight) during an $8 \mathrm{~h}$ continuous infusion of (O) $\mathrm{L}$-[side-chain $\left.2,3^{-}{ }^{3} \mathrm{H}\right]$ tyrosine $(57 \mathrm{l} \mu \mathrm{Ci} / \mathrm{h})$ and $(0), \mathrm{L}-\left[4,5^{-}{ }^{3} \mathrm{H}\right]$ leucine $(\mathrm{I} 04 \mu \mathrm{Ci} / \mathrm{h}$ ).

Table 2. Daily fractional rates of synthesis $\left(\mathrm{k}_{\mathrm{r}, \mathrm{b}}{ }^{*}\right.$ and $\left.\mathrm{k}_{\mathrm{r}, \mathrm{b}} \dagger ; \times 100\right)$ of protein for tissues and the whole body of two heifers (nos. 439 and 440 ) and a cow (no. 981) $\ddagger$

$\begin{array}{cccccccc}\begin{array}{c}\text { Animal } \\ \text { no. }\end{array} & & \text { Muscle } & \text { Carcass } & \text { GIT } & \text { Liver } & \text { Hide } & \begin{array}{c}\text { Whole } \\ \text { body } \S\end{array} \\ 439 & k_{s, h} & \mathrm{I} \cdot 82 & 3.8 \mathrm{I} & 53.21 & 38.48 & 7.38 & 8.00 \\ & k_{s, b} & \mathrm{I} \cdot 64 & 3.50 & 28.02 & 10.82 & 3.55 & 4.97 \\ 440 & k_{s, h} & 2.08 & 2.80 & 52.23 & 26.32 & 4.83 & 6.30 \\ & k_{s, b} & \mathrm{I} \cdot 83 & 2.47 & 23.31 & 10.00 & 3.15 & 3.88 \\ 98 \mathrm{I} & k_{s, h} & 0.93 & \mathrm{I} \cdot 63 & 29.0 \mathrm{I} & 14.69 & 3.88 & 3.86 \\ & k_{s, \mathrm{~b}} & 0.84 & \mathrm{I} \cdot 46 & 14.58 & 7.38 & 1.42 & 2.36\end{array}$

* Calculated assuming specific radioactivity (SR) free tyrosine in the homogenate defines precursor SR.

$\dagger$ Calculated assuming SR of free tyrosine in the blood defines precursor SR.

$\ddagger$ For details of animals, see p. 492.

$\S$ Calculated as $\frac{\sum \text { (fractional rate of synthesis of tissue } \times \text { tissue protein) }}{\text { total protein }}$.

Whole body synthesis estimated from flux and tissue labelling

The total protein synthesized $(\mathrm{g} / \mathrm{d})$ in each tissue was calculated as the product of fractional rate of synthesis $\times$ total protein. The sum of these products provided two estimates $\left(A_{s, b}\right.$, $\left.A_{s, h}\right)$ of whole-body protein synthesis and these are shown in Table 3 . Alternative estimates of body protein synthesis were obtained from the fluxes of blood free tyrosine and leucine 
Table 3. Total protein synthesis $\left(\mathrm{A}_{\mathrm{s}, \mathrm{b}}{ }^{*}, \mathrm{~A}_{\mathrm{s}, \mathrm{b}} \dagger ; g / d\right)$ in individual tissues of two heifers (nos. 439 and 440) and a cow (no. 981)

(Whole-body synthesis was estimated as the sum of tissue protein synthesis or from the total fluxes of leucine or tyrosine)

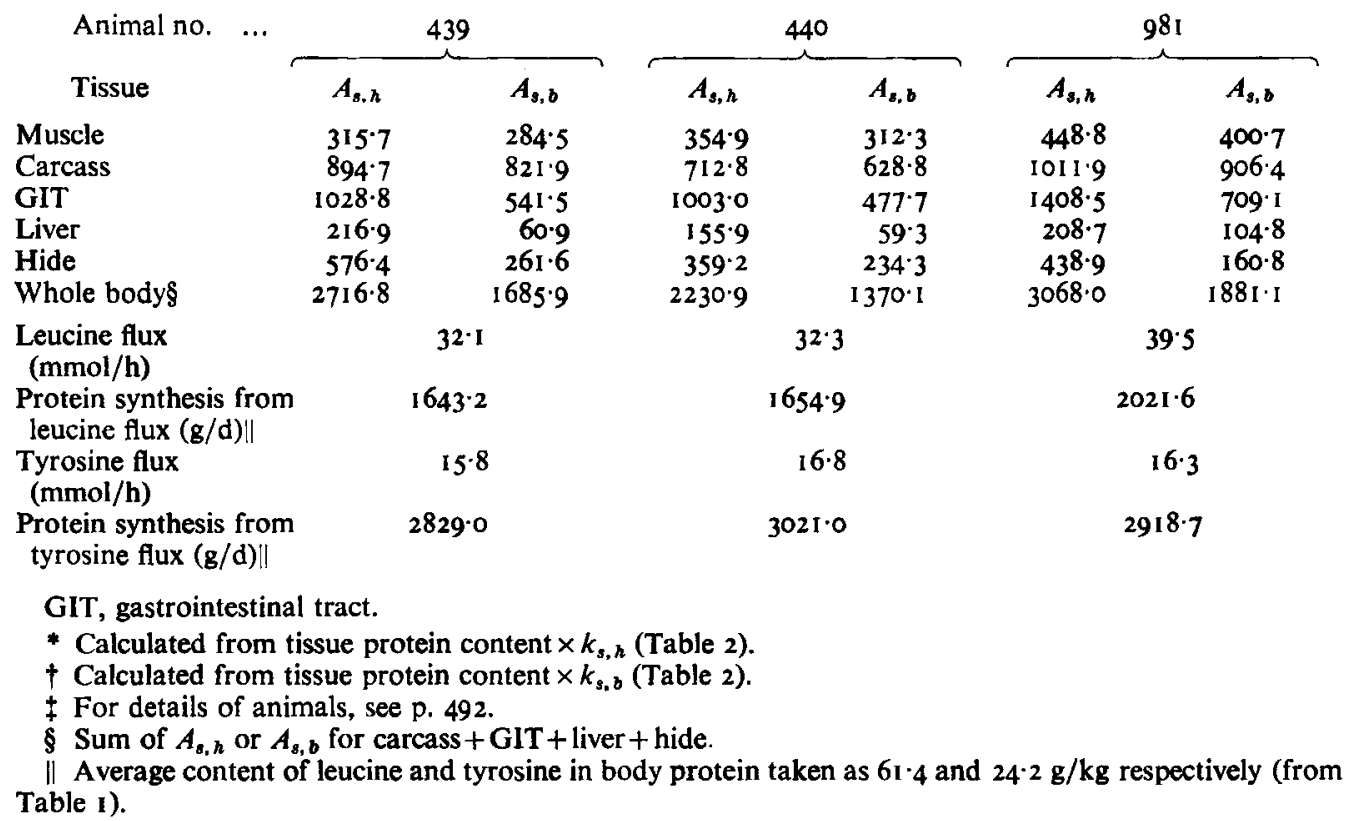

(Table 3). These values represent the rate of irreversible loss of radioisotope into protein synthesis and amino acid catabolism, and if the latter can be determined then an estimate of synthesis is obtained by difference. It has been suggested that in pigs total amino acid catabolism can be estimated from the urinary elimination of urea and ammonia (Reeds et al. 1978). While such an approach may not be appropriate in cattle, due to ammonia production by fermentation processes in the rumen, nevertheless the amount of urea and ammonia eliminated will probably provide an upper estimate of total amino acid catabolism. On this basis catabolism amounted to the equivalent of 215 (heifers nos. 439 and 440 ) and 306 (cow no. 98I) g protein/d and this represents less than $15 \%$ of the amino-N flux estimated from leucine turnover. There were, however, large differences in the whole-body protein synthesis estimated from the total fluxes of tyrosine and leucine (Table 3).

The contribution of each tissue to whole-body synthesis was also calculated (Table 4). The actual percentage contribution of each tissue was dependent on which estimate for total synthesis was used but when compared against the same whole-body value all tissues showed very similar contributions (Table 4).

\section{DISCUSSION}

\section{Validity of methods}

The technique of constant infusion of radioactive amino acids to measure rates of protein synthesis in both the whole body and in individual tissues has been widely adopted following the pioneer development work on this method by Waterlow and his colleagues (Waterlow \& Stephen, 1967; Garlick et al. 1973). Use of this procedure to measure protein synthesis in 
Table 4. Percentage contribution of each tissue to total body synthesis $\left(\mathrm{A}_{\mathrm{a}, \mathrm{i}}{ }^{*}\right.$, and $\left.\mathrm{A}_{\mathrm{s}, \mathrm{b}} \dagger\right)$ and percentage contribution of muscle synthesis $\left(\mathrm{A}_{\mathrm{n}, \mathrm{h}}\right.$ and $\left.\mathrm{A}_{\mathrm{a}, \mathrm{b}}\right)$ to total synthesis estimated from flux of leucine for two heifers (nos. 439 and 440) and one cow (no. 98I) $\ddagger$

\begin{tabular}{|c|c|c|c|c|c|c|c|c|}
\hline $\begin{array}{c}\text { Animal } \\
\text { no. }\end{array}$ & & Muscle & Carcass & GIT & Liver & Hide & $\frac{\text { Muscle } A_{a_{1},}}{A_{s, \text { Ren }} \S}$ & $\frac{\text { Muscle } A_{s, p}}{A_{s, \text { new }} \S}$ \\
\hline 439 & $\begin{array}{l}A_{s, h} \\
A_{s, b}\end{array}$ & $\begin{array}{l}11 \cdot 6 \\
16 \cdot 9\end{array}$ & $\begin{array}{l}32 \cdot 9 \\
48 \cdot 8\end{array}$ & $\begin{array}{l}37 \cdot 9 \\
32 \cdot 1\end{array}$ & $\begin{array}{l}8 \cdot 0 \\
3 \cdot 6\end{array}$ & $\begin{array}{l}21 \cdot 2 \\
15 \cdot 5\end{array}$ & $19 \cdot 2$ & $17 \cdot 3$ \\
\hline 440 & $\begin{array}{l}A_{s, n} \\
A_{s, b}\end{array}$ & $\begin{array}{l}15.9 \\
22.8\end{array}$ & $\begin{array}{l}32 \cdot 0 \\
45 \cdot 9\end{array}$ & $\begin{array}{l}45 \cdot 0 \\
32 \cdot 7\end{array}$ & $\begin{array}{l}7 \cdot 0 \\
4 \cdot 3\end{array}$ & $\begin{array}{l}16 \cdot 1 \\
17 \cdot I\end{array}$ & $2 I \cdot 4$ & I 8.9 \\
\hline 981 & $\begin{array}{l}A_{s, h} \\
A_{s, b}\end{array}$ & $\begin{array}{l}14 \cdot 5 \\
21 \cdot 3\end{array}$ & $\begin{array}{l}33 \cdot 0 \\
48 \cdot 2\end{array}$ & $\begin{array}{l}45 \cdot 9 \\
37 \cdot 7\end{array}$ & $\begin{array}{l}6 \cdot 8 \\
5.6\end{array}$ & $\begin{array}{r}14 \cdot 3 \\
8 \cdot 5\end{array}$ & $22 \cdot 2$ & 19.8 \\
\hline & \multicolumn{8}{|c|}{$\begin{array}{l}\text { GIT, gastrointestinal tract. } \\
\left.\text { * Calculated as }\left(\left(\text { tissue } A_{s, n}\right) \div\left(\text { whole body } A_{s, n}\right)\right) \times \text { I00 (from Table } 3\right) \text {. } \\
+ \text { Calculated as }\left(\left(\text { tissue } A_{s, b}\right) \div\left(\text { whole body } A_{s, b}\right)\right) \times \text { I00. } \\
\ddagger \text { For details of animals, see } p .492 \text {. } \\
\S \text { Whole-body protein synthesis estimated from total leucine flux (Table } 3) \text {. }\end{array}$} \\
\hline
\end{tabular}

tissues is dependent on the attainment of a 'plateau' specific radioactivity in the pool of free amino acids from which the t-RNAs are charged and, further, presupposes knowledge of the rate at which the plateau is attained. Changes in the specific radioactivity of the precursor amino acid for polypeptide formation were not measured directly in this study. Rather it was assumed that the changes in the specific radioactivity of the free tyrosine in the blood also represents changes in the free tyrosine of the tissues and the precursor pool. The greatest uncertainty concerns the magnitude of the specific radioactivity of the immediate precursor, direct determination of which is a lengthy process (Airhart et al. 1974; Ilan \& Singer, 1975). For most practical purposes estimates are based on the assumption that the specific radioactivity of the immediate precursor is similar to that of the free amino acid in either the blood or the tissue homogenate. The controversy as to which, if either, of these better defines the specific radioactivity of the precursor is still not settled (see review by Waterlow et al. 1978) but it is assumed that, for most tissues and most, but not all, amino acids (Robins, 1979) the true value will lie within these limits. For this reason in the present study rates of synthesis are expressed relative to the values of free tyrosine in both blood and the relevant tissue.

\section{Comparison of the fluxes of leucine and tyrosine}

Whole-body flux is a measure of the rate of irreversible loss (within the time-scale of the experiment) of isotope from the pool of free amino acids in the blood. This loss is either by incorporation into protein or by oxidation and consequently the large differences between the fluxes of tyrosine and leucine shown in Table 3 must be due to the differences in the magnitude of one, or both, of these processes. Unless the average contribution of tyrosine or leucine or both in the protein which is synthesized is markedly different from that of the protein actually deposited, then the component of protein synthesis in the total flux should be similar for the two amino acids. In addition, protein synthesis measured as $A_{b, b}$ should approximate to that estimated from the flux as both are functions of the isotope passing from the free amino acid in the blood. While the values for $A_{s, b}$ for tyrosine were similar to those for total leucine flux they were considerably lower than those for the total flux of tyrosine (Table 3 ) and this suggests that the latter includes a considerable component of oxidation.

In ruminants the supply of dietary $\mathbf{N}$ is mainly via microbial protein and consequently 
the pattern of absorbed amino acids is fairly constant (see Wolff et al. 1972; Hume et al. 1972). This microbial protein is rich in tyrosine and phenylalanine and poor in leucine relative to the mean composition of the body protein of the animal (see MacRae \& Reeds, 1979). As tyrosine is an intermediate on the major pathway of phenylalanine catabolism, the degradation of phenylalanine will increase the apparent oxidation of tyrosine. Thus, in sheep, for each I mol leucine absorbed there is an uptake of tyrosine and phenylalanine $0.6 \mathrm{~mol}$ in excess of requirements for protein maintenance or gain (Wolff et al. 1972). If the latter values are extended to the cattle in the present study, where there is an apparent excess in the flux of tyrosine over that of leucine of $5-6 \mathrm{mmol} / \mathrm{h}$, then the differences could be accounted for by the daily absorption of $350-420 \mathrm{~g}$ largely microbial protein from the gut, probably a realistic value in these animals. This hypothesis that the high flux of tyrosine in cattle contains a large oxidation component will need to be confirmed by direct experimentation.

Most whole-body measurements of flux have involved the use of either lysine, tyrosine or leucine. The first two were the earliest introduced, as enzymic methods were available for their determination (Waterlow \& Stephen, 1967; Garlick \& Marshall, 1972), but few direct comparisons of any of these amino acids have been reported. The relative estimates of protein synthesis from total flux do seem to depend not only on the amino acid used but also the species studied. The higher flux of tyrosine compared with leucine noted in the present study for cattle is in contrast to the situation in the Zucker rat, where estimates of protein synthesis based on the total flux of tyrosine were much lower than those based on that of leucine (P. J. Reeds and G. E. Lobley, unpublished results). In the pig the two amino acids appear to give fluxes which provide similar estimates of protein synthesis (P. J. Reeds and G. E. Lobley, unpublished results). Direct comparisons of lysine and leucine have been studied in humans and pigs. In man the total flux of lysine is $12-28 \%$ lower than that of leucine (Motil et al. 1979). In pigs the difference is even greater, total protein flux estimated from lysine being only $35 \%$ of that estimated from leucine (from Simon, Münchmeyer et al. 1978). This apparent incompatibility in the pig could not be attributed primarily to differences in oxidation, as the age, weight and nutritional regimen of the animals described by Simon, Münchmeyer et al. (1978) was similar to that reported by Reeds et al. (1978), where oxidation of leucine was measured as only $12-14 \%$ of total flux. More probably, the reason for the differences between the two amino acids in the pig is that the lysine precursor for protein synthesis has a specific radioactivity at most $50 \%$ that of the blood.

In the majority of studies, estimates of protein synthesis from the flux of an amino acid are used mainly on a comparative basis for animals of one species and, as such, provide useful relative information. Difficulties arise, however, when inter-species comparisons need to be made from values based on different amino acids and when the contributions of individual tissues are compared against different base flux measurements.

\section{Contribution of individual tissues to total synthesis}

The contributions of individual tissues to total synthesis have some interesting implications for the efficiency of growth. The highest contribution that could be attributed to skeletal muscle was only $25 \%$ and, as at least $50 \%$ of daily $\mathrm{N}$ retention is as muscle protein, this suggests that the efficiency of deposition (i.e. protein deposited:protein synthesized) is much higher for muscle than for any of the other major tissues. From the results it would appear that the heifers deposited muscle protein with an efficiency of I $8 \%$ compared with less than $5 \%$ for total body protein.

Despite the differences in the ages and growth rates of the cattle studied the contribution of the individual tissues to total synthesis was remarkably constant (Table 4). Using tech- 
Table 5. Percentage contribution of muscle protein synthesis to whole-body protein synthesis in different species

(Values presented in the original form and recalculated against whole-body protein synthesis estimated from leucine flux and also adjusted for differences in carcass composition)

\begin{tabular}{|c|c|c|c|c|}
\hline Species & $\begin{array}{l}\text { Body-wt } \\
\text { (kg) }\end{array}$ & Reference & $\begin{array}{l}\text { Original } \\
\text { values }\end{array}$ & $\begin{array}{l}\text { Recalculated } \\
\text { values }\end{array}$ \\
\hline Rat & 0.1 & Garlick et al. (1975) & 19 & - \\
\hline Rat & 0.2 and 0.35 & $\begin{array}{l}\text { Lobley, Reeds \& Webster } \\
\text { (unpublished results) }\end{array}$ & - & $14-20$ \\
\hline Rabbit, adult & 3.8 & Nicholas et al. (1977) & 12 & $I^{8}-2 I^{*}$ \\
\hline Pig & 24 & et al. $(1$ & 62 & 24 \\
\hline Pig & 30 & tet al. (1978) & - & \\
\hline & 75 & al. (1970) & 42 & $26 \| \pi$ \\
\hline , newborn & $2-7$ & & - & $28 * *$ \\
\hline Shee & 35 & Arr & - & $19+t$ \\
\hline She & $40-5$ & & & $23 t+t \ddagger$ \\
\hline , adult & $62-80$ & $\mathrm{Hal}$ & $40-62$ & - \\
\hline Human, adult & & Iunro (1978) & $20-26$ & - \\
\hline Catt & $236-628$ & Present st & - & $19-22$ \\
\hline \multicolumn{5}{|c|}{ 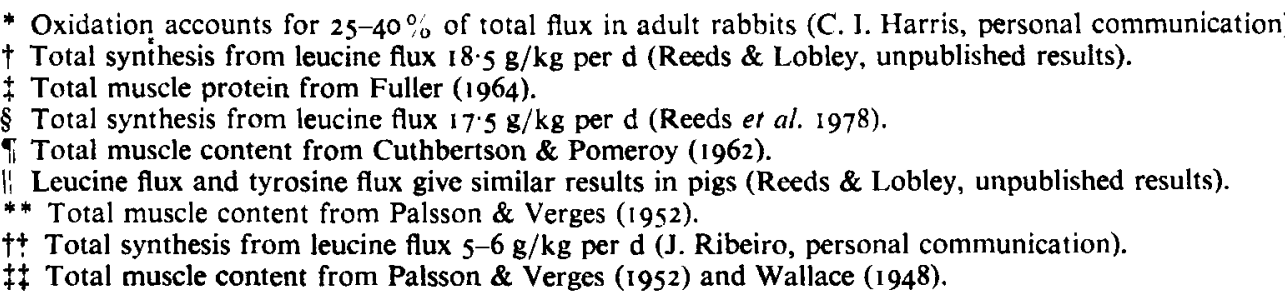 } \\
\hline
\end{tabular}

niques similar to those described in this study Lobley, Webster et al. ( 1978 and unpublished results) have shown that in both lean and obese Zucker rats the major tissues also make constant contributions to total synthesis and in general are similar to those found for the cattle in this study. There are few values available for the contributions of individual tissues, except for skeletal muscle in other species. The percentage of total synthesis attributed to skeletal muscle has been reported as between 12 and $62 \%$ (Table 5). The estimates have, however, been based on calculation of whole-body synthesis from the fluxes of different amino acids and, as discussed previously, these do not always result in similar values. Furthermore, in some of the studies total muscle protein has been assumed as a proportion of the live weight of the animal, and the values used have not always been realistic. In an attempt to obtain a more sound inter-species comparison available information on carcass composition has been combined with the original fractional synthesis rates to give total amount of muscle protein synthesized daily and this has been expressed relative to the total leucine flux or, where possible, whole-body protein synthesis estimated from this (Table 5). Expressed on this basis the contribution of muscle is between 14 and $33 \%$ for a wide variety of animals of different species, different ages and on different nutritional regimens.

The original and recalculated forms of the results in Table 5 lead to fundamentally different hypotheses about the control of protein synthesis and accretion. If the contribution of an individual tissue, such as skeletal muscle, varies considerably both within and between species, as the original values suggest, then the control mechanisms, or at least their magnitude, must also differ, and furthermore control can be exerted on a single tissue. This also suggests that the response of different species to exogenous manipulation of protein metabolism may also vary. On the other hand, if the contribution of tissues to total protein synthesis is fixed then they could respond to a stimulus in similar proportion. Such a hypo- 
thesis would not require tissue-specific control systems for conditions where neither energy nor protein is limiting. Inter-species response to stimuli of protein metabolism might also be similar.

\section{Total protein synthesis and energy costs}

Although there is controversy over the nature of the amino acid precursors of protein synthesis, and hence whether $A_{a, b}$ or $A_{a, b}$ represents more closely the true daily synthesis, it is agreed that $A_{s, b}$ will be the minimum amount of protein synthesized. Thus, the two heifers synthesized $14.1 \cdot 7 \mathrm{~kg}$ of protein/ $\mathrm{d}$ and in the same time would have only deposited approximately I 5-20 g N, predicted from their weight gains. Even the cow, which was on a near-maintenance ration and must have had an $\mathrm{N}$ balance close to zero, synthesized (and degraded) a minimum of $\mathrm{I} \cdot 9 \mathrm{~kg}$ protein $/ \mathrm{d}$.

The mechanism for formation of a peptide bond is assumed to entail the hydrolysis of four to five ATP molecules i.e. an energy cost of $4.5 \mathrm{~kJ} / \mathrm{g}$ protein synthesized (Millward et al. 1976; Webster et al. 1978). The latter would represent an energy requirement for total protein synthesis of $6.1,7.5$ and $8.4 \mathrm{MJ} / \mathrm{d}$ based on $A_{s, b}$ for the three animals, and 9.9 , $12 . \mathrm{I}$ and $13.6 \mathrm{MJ} / \mathrm{d}$ based on $A_{n, h}$. The heat productions were not measured directly in these animals but from their weights and growth rates it can be estimated that heat loss for the heifers would be approximately $39 \mathrm{MJ} / \mathrm{d}$ and for the cow $58 \mathrm{MJ} / \mathrm{d}$. Thus, based on $A_{a, b}$ the energy costs of protein synthesis would account for $14-19 \%$ of heat production, and based on $A_{s, h}$ the values would increase to $24-31 \%$. Similar contributions of protein synthesis to total energy requirement has been calculated for pigs, man and rats (Garlick et al. 1976) and rabbits (Nicholas et al. 1977), and this indicates that, unless either protein synthesis or its energy costs have hitherto been severely underestimated, then it represents less than one-third of the energy expenditure of an animal.

The authors gratefully acknowledge the assistance received from Messrs K. Rae and D. Mathers for the care of the animals, from Dr F. White and Mr J. Gunn for the catheterization procedures, and from Mr G. A. M. Sharman for the slaughter and rapid excision of tissues.

\section{REFERENCES}

Airhart, J., Vidrich, A. \& Khairallah, E. A. (1974). Biochem. J. 140, 539.

Arnal, M., Ferrara, M. \& Fauconneau, G. (1978). Proc. 29th Mtg Eur. Ass. Anim. Prod., p. 1. Stockholm, Sweden.

Buttery, P. J., Beckerton, A. \& Lobbock, M. H. (1977). Proc. 2nd int. Symp. Protein Metab. Nutr., p. 32. Flevohof, The Netherlands.

Buttery, P. J., Beckerton, A., Mitchell, R. M., Davies, K. \& Annison, E. F. (1975). Proc. Nutr. Soc. 34, $91 \mathrm{~A}$.

Cuthbertson, A. \& Pomeroy, R. W. (1962). J. agric. Sci., Camb. 59, 215.

Davidson, J., Mathieson, J. \& Boyne, A. W. (1970). Analyst, Lond. 95, 181.

Edmunds, B. K., Buttery, P. J. \& Fisher, C. (1978). Proc. Nutr. Soc. 37, 32A.

Fawcett, J. K. \& Scott, J. E. (1960). J. clin. Path. 13, 156.

Fell, B. F. (I96I). J. Path. Bact. 81, 25 I.

Firschein, H. E. \& Shill, J. P. (1 966). Analyt. Biochem. 14, 296.

Fuller, M. F. (1964). The effects of some climatic factors on the growing pig. Ph.D. Thesis, University of Cambridge.

Garlick, P. J., Burk, T. L. \& Swick, R. W. (1976). Am. J. Physiol. 230, 1108.

Garlick, P. J. \& Marshall, I. (1972). J. Neurochem. 19, 577.

Garlick, P. J., Millward, D. J. \& James, W. P. T. (1973). Biochem. J. 136, 935.

Garlick, P. J., Millward, D. J., James, W. P. T. \& Waterlow, J. C. (1975). Biochem. biophys. Acta. 414, 7 I. Halliday, D. \& McKeran, R. O. (1975). Clin. Sci. mol. Med. 49, 581.

Hume, I. D., Jacobson, D. R. \& Mitchell, G. E. Jr (1972). J. Nutr. 102, 495.

Ilan, J. \& Singer, M. (1975). J. mol. Biol. gr, 39.

James, W. P. T., Garlick, P. J., Sender, P. M. \& Waterlow, J. C. (1976). Clin. Sci. mol. Med. 50, 525. 
Lobley, G. E. \& Lovie, J. M. (1979). Biochem. J. r82, 867.

Lobley, G. E., Reeds, P. J. \& Pennie, K. (1978). Proc. Nutr. Soc. 37, 96A.

Lobley, G. E., Webster, A. J. F. \& Reeds, P. J. (1978). Proc. Nutr. Soc. 37, 20 A.

MacRae, J. C. \& Reeds, P. J. (1979). In Protein Deposition in Animals [P. J. Buttery and D. B. Lindsay, editors]. London: Butterworths. (In the Press.)

Marsh, W. H., Fingerhut, B. \& Miller, H. (1965). Clin. chem. 11, 624.

Millward, D. J., Garlick, P. J. \& Reeds, P. J. (1976). Proc. Nutr. Soc. 35, 339.

Motil, K. J., Matthews, D., Rohrbaugh, D., Brier, D., Burke, J. F. \& Young, V. R. (1979). Fedn Proc. Fedn Am. Socs exp. Biol. 38, 2533 Abstr.

Nicholas, G. A., Lobley, G. E. \& Harris, C. I. (1977). Br. J. Nutr. 38, I.

Palsson, H. \& Verges, J. B. (1952). J. agric. Sci., Camb. 42, I.

Perry, S. V. \& Zydowo, M. (1959). Biochem. J. 71, 220.

Reeds, P. J., Fuller, M. F., Lobley, G. E., Cadenhead, A. \& McDonald, J. D. (1978). Proc. Nutr. Soc. 37, I06A.

Robins, S. P. (1979). Biochem. J. 181, 75.

Simon, O., Bergner, H. \& Wolf, E. (1978). Arch. Tierernähr. 28, 629.

Simon, O., Münchmeyer, R., Bergner, H., Zebrowska, T. \& Buraczewska, L. (I978). Br. J, Nutr. $40,243$.

Soltesz, G., Joyce, J. \& Young, M. (1973). Biol. Neonate 23, 139.

Wallace, L. R. (1948). J. agric. Sci., Camb. 38, 367.

Waterlow, J. C., Garlick, P. J. \& Millward, D. J. (1978), Protein Turnover in Mammalian Tissues and in the Whole Body. Amsterdam: North Holland.

Waterlow, J. C. \& Stephen, J. M. L. (1967). Clin. Sci. 33, 489.

Webster, A. J. F., Lobley, G. E., Reeds, P. J. \& Pullar, J. D. (1978). Proc. Nutr. Soc. 37, 2 I A.

Wolff, J. E., Bergman, E. N. \& Williams, H. H. (1972). Am. J. Physiol. 223, 438.

Young, V. R. \& Munro, H. N. (1978). Fedn Proc. Fedn Am. Socs exp. Biol. 37, 229 I. 